\title{
JAPANESE IMMIGRATION INTO KOREA
}

\section{By Thomas F. Millard,}

New York City; Author of "The New Far East" and "America and the Far Eastern Question."

In modern times immigration may be divided roughly into two classes: persons who come to a country with purpose to establish a permanent residence, acquire citizenship, and adapt themselves to its institutions; and persons who, because of their own disinclination, or from being prevented by laws of the nation, do not become subjects or citizens of the state where they reside, occupying the situation of foreign residents.

Japanese immigrants into Korea do not fall exactly within either of these classes. Indeed, they hardly can be termed immigrants in a political sense, since by moving from Japan into Korea their general political status undergoes no material alteration. They still are Japanese subjects living in a country governed by Japan; and it is improbable that this condition will ever be modified. To-day Japan is absolute sovereign in Korea, and exercises unrestrained all functions of government, although a Korean emperor is presumed to reign and a Korean ministry nominally exercises some administrative authority.

Japanese immigration into Korea, therefore, does not present a political problem in an international sense; and consequently is interesting rather in its economic and sociological phases, from which some conclusions may perhaps be deduced that will bear upon the question of Asiatic immigration into the United States. In this connection, the thesis of Japan's administration in Korea should be considered, for it affords a basis for estimating certain effects of her policy. Obviously, the policy is paternal in conception and operation, in the sense that it assumes that Koreans are incompetent to govern themselves. This is the theory of many similar policies, of which British administration in Egypt and India, Dutch rule in the East Indies, and American government of the Philippines are prominent instances. Of these examples, Japan's rule in Korea is more like Dutch colonial administration; but it differs, in the matter of (403) 
immigration, from all of them. In the case of Great Britain, Holland and the United States, the paternal relation is exercised by a race not adaptable, in large numbers, to life in the regions thus brought under their authority; and so the immigration of English into India, Dutch into the East Indies and Americans into the Philippines in no way threatens to disturb economic and sociological conditions, nor to seriously affect, except by influence of association and example, the native inhabitants. In respect to their Oriental dependencies, the western nations mentioned have never attempted to colonize them with British, Dutch or American immigrants who would or could directly compete with the natives in their accustomed vocations; and in the Philippines the United States protects the natives against Chinese immigration.

Conditions in Korea are different. The country is very like Japan in soil, climate and natural resources. While various divisions of Oriental races present external differences, and to close observation display some diverse traits, they really involve no greater divergences than do the Caucasian nations of Europe, or inhabitants of different parts of the United States. There is little difference between Chinese, Japanese and Koreans as to general characteristics. Owing to peculiar conditions which obtained for so long, Koreans are somewhat less sophisticated than Chinese and Japanese; and from having lived for centuries in a land of comparative plenty, they have not the industrial capability and commercial acumen which a harder struggle for existence has instilled into their neighbors. Until the empire was opened to foreign trade want was comparatively unknown, and the country produced more than enough to supply the needs of the population. With an area less than that of Kansas, Korea has a population approximately of 10,000,000.

While Korea is well populated, there always was land to spare until within the last few years. Growth of foreign trade, and the consequent exportation of foodstuffs, brought the Korean peasant into competition with his Oriental neighbors, and soon caused his situation to be modified by submitting him to a new economic pressure. He now had to labor not only to meet his own simple requirements, but was for the first time forced to sell his products in a general market. Unused land began to have value, and as the cost of living appreciated, the condition of the peasants, who never had been compelled to practice thrift, relatively deteriorated. 
This was the situation when the sovereignty of Japan was established by seizure of Korea, in I904, and when the tide of Japanese immigration into the country began to swell. There were some Japanese in Korea before the Russo-Japanese War, and they were accorded the same privileges and rights there as other foreigners; yet there never was any great influx. Natural conditions in no way have been changed by the establishment of Japanese rule there. Korea is no nearer to Japan than before. It is somewhat more accessible, in a modern sense, owing to railway communications and better shipping facilities; but for hundreds of years Japanese fishermen have plied Korean waters in their boats, and had conditions tempted them there was no serious obstacle to prevent them from immigrating in large numbers. The reason they did not do so seems to be because Korea offered no especial inducement to Japanese immigrants. A Japanese trader or peasant formerly had no greater opportunities in Korea than in Japan, and so, except some adventurous persons, they remained at home.

An explanation for the Japanese immigration into Korea since 1904 must, therefore, be sought apart from natural conditions; and investigation of the factors involved indicate that politics rather than economics provided the incentive for it. It is a result of a deliberate colonization policy of the Japanese government. The broader purposes of Japan in wishing to colonize Korea with Japanese are almost self-evident, and perhaps are well enough understood to not require elucidation in this connection. Assuming that the Japanese government desires to induce 5,000,000 Japanese to settle in Korea (which is a number mentioned in discussion in the Diet), it must excite among them a desire to go to Korea, and secure contentment for them when they go. In time the success of the plan will depend upon the latter contingent, for unless Japanese immigrants in Korea are satisfied they will not remain, and the project to Jap-ize the country will fail.

In creating among Japanese a desire to go to Korea the government employed all of several means which it controls: publicity, the shipping lines and the emigration companies being the more important. The affiliation of emigration companies in Japan with the government, through the subsidized shipping companies, is very close; and when backed by the government, with the advantage of special transportation rates, it was not difficult for them to induce (405) 
many Japanese to take a chance in the new country. I have no authentic figures showing the extent of Japanese immigration into Korea during the last five years; but unofficial statistics fix it at 85,000 in $1904,115,000$ in $1905,120,000$ in 1906 , and 60,000 in 1907. When I was last in Korea, in I908, the number of Japanese in the country was estimated at less than 500,000 . The high-water mark of this immigration was reached in 1906.

The turn of the tide, notwithstanding extraordinary inducements afforded by preferential treatment both in getting to Korea and establishing settlers there, probably caused the Diet to grant a charter to the Oriental Colonization Company, which was organized in 1908 with a capital of $10,000,000.00$ yen, and which receives an annual subsidy of $300,000.00$ yen from the government in the form of guarantee of interest on debentures. This company has a one hundred year franchise, and is equipped with a blanket charter. The Diet has authorized it to issue debentures for $20,000,000.00$ yen, and two members of the ministry were in the company's first directorate.

The charter thus enumerates the enterprises in which the Oriental Colonization Company may engage :

I. Agriculture.

2. Sale, purchase, leasing and hiring of lands necessary for colonization purposes.

3. Undertakings connected with land and its control.

4. Construction, sale, purchase and renting of necessary buildings.

5. Collection and distribution of Japanese and Korean colonists.

6. Supply of seeds, seedlings, fertilizers and other materials for industries to Japanese and Korean farmers.

7. Supply to Japanese immigrants and Korean farmers of building materials, utensils and machinery for industrial purposes; ships, wagons and domestic cattle.

8. Selling, buying, transportation and storing of all things produced by Japanese immigrants and Korean farmers as well as of the necessities of life for them.

9. Supply of funds necessary for colonization purposes.

\section{Supplementary Enterprises}

(a) Marine industries.

(b) Mining.

(c) Manufacturing industries that derive their materials from agricultural and marine products.

(d) Other undertakings deemed necessary for colonization. 
In the Diet, government deputies stated that the fundamental object of the Oriental Colonization Company is to send skilled Japanese farmers to Korea to reclaim the considerable extent of arable lands now lying in waste there. The charter confines the enterprise exclusively to Japanese and Koreans, and a majority of officers and employees must be Japanese. Here is a revival of the old East India Company, with the additional power to colonize on a great scale. While, when interrogated in the Diet, government deputies denied that the charter of the company constitutes a monopoly of any kind of business in Korea, it easily may do so when one considers its relation to the Japanese government and the whole policy of the latter in Korea. It may be said that Korean participation in the Oriental Colonization Company is merely a fiction, and similar to the part played by the emperor and the socalled Korean ministry in administrative affairs.

An idea of the effect of injection into Korea of several millions of Japanese, if the scheme of the Oriental Colonization Company proves successful, may perhaps be gleaned from certain results of the presence of those already domiciled there. That most Japanese immigrants would be inferior to the social average in Japan might be expected, for the better classes of Japanese are not disposed to such doubtful adventure. Japanese in Korea are of all classes, from officials of the superior type to coolies. An argument is advanced that the settling of Japanese farmers upon land that is now unproductive will develop the country. So it might; but it appears that of the half a million Japanese who have come to Korea since Japan took the country less than three thousand are engaged in agricultural pursuits. When last in Seoul I made inquiry about this matter, and obtained from as reliable and unprejudiced a source (not Japanese) as I could find the following estimate of occupations of Japanese immigrants:

I. Officials $\ldots \ldots \ldots \ldots \ldots \ldots \ldots \ldots \ldots \ldots \ldots \ldots \ldots \ldots \ldots \ldots \ldots \ldots \ldots, 5,000$

2. Traders (including peddlers, merchants, etc., with their families) . . 100,000

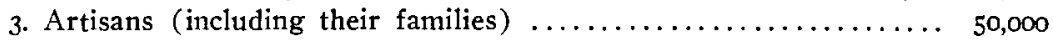

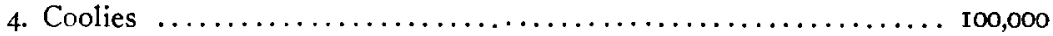

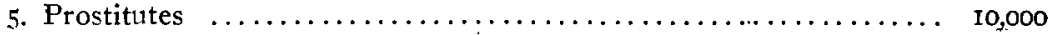

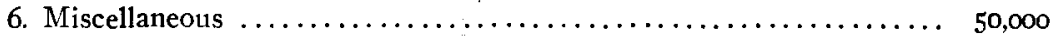

7. Subordinate government employees, police, etc. ........... ro,oo

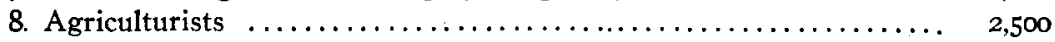


Within the last two years a large number of Japanese have returned to Japan, which probably accounts for the discrepancy between the total of this estimate and the total immigration since I904. This estimate does not include the Japanese military. A striking result of Japanese administration is that the number of Japanese officials and employees in the Korean government now exceeds the Koreans, who are being removed from even the meanest occupations to make way for Japanese. What probably will impress the sociological student in this estimate is that the Japanese immigration is of a character directly to compete with the native population. Instead of opening new avenues of production, this immigration so far merely has brought an additional population to live upon the present resources of the country, which means that it has had the immediate effect of accentuating the struggle for existence, and has subjected Koreans to a severe and unfamiliar competition.

The character of this competition can only be appreciated when political conditions in Korea under Japan's rule, and its application to the situation of the natives, are understood; and as I lack space in this paper to give details illustrating this phase of the matter, I will repeat a summary which is included in my recent work "America and the Far Eastern Question:"

"The scope of this work will not permit relation in detail of detriments which Koreans of all classes suffer under the Japanese regime. Bare mention of specific instances which, supported by reliable testimony, were called to my attention during my last visit would fill pages. These detriments may be summarized as follows: Siezure of land and other property of Koreans by Japanese without proper compensation or legal warrant; exclusion of Koreans from participation in commercial and industrial development of the country; subjection of Koreans to abuse and indignities at the hands of Japanese immigrants, military and civil officials; the practical impossibility for Koreans, except in flagrant cases, to obtain justice in issues against Japanese; superior advantages of Japanese over Korean tradesmen and merchants, through preferential treatment accorded by the Japanese administration; debauching of Korean morals by Japanese immigrants, by the introduction of thousands of Japanese prostitutes and by the introduction of pernicious vices, such as opium and lotteries. The detriments thus summarized are not based upon scarce or isolated cases, but are so numerous and (408) 
widespread as unmistakably to indicate that they are the result partly of premeditated general policy, and partly due to laxity and indifference of Japanese administrators."

The truth is that Japanese in Korea demean themselves not as ordinary immigrants, but as overlords; and this is as true of the Japanese coolie, in his sphere, as it is of the highest official. The average Japanese in Korea assumes the attitude of conqueror, and seems to regard Koreans as an inferior and subject race. Moreover, they are supported in this attitude by the policy of the Japanese government, and by actions of Japanese officials in Korea. Indeed, the plight of a Korean in his own country is now a sorry one; yet, curiously enough, he may not himself emigrate without permission of the Japanese authorities. Recently, acting upon representations of Japanese emigration companies and their affiliated interests, the Residency [Japanese administration in Korea] made new regulations affecting Korean emigration. This regulation is ostensibly designed to "protect" Koreans who emigrate to foreign countries. In recent years there has been little Korean emigration except to Hawaii and Mexico, where it competes with Japanese immigrants in the labor field. The new regulations make it practically impossible for Koreans to emigrate except under conditions which discourage such disposition. To believe that any solicitude for Koreans animates the Japanese government in this matter taxes the credulity of anyone who is familiar with conditions in Korea.

It is probable that this brief criticism of some effects of Japanese immigration into Korea will interest Americans chiefly by whatever light it throws upon its predominating characteristics. Japanese immigrants into Korea are not responsible for the Korean policy of Japan, but their demeanor under the circumstances is interesting and perhaps illuminating. That Japanese of all classes in Korea are, in their attitude toward the natives and institutions of the country, contemptuous, truculent and overreaching is my firm conviction; and as their political and social situation there is favorable, compared to that of Japanese immigrants to western countries, their conduct may afford an insight into what they might do elsewhere should circumstances permit. 